CASE REPORT

\title{
Ventricule-shunt abdominal complications
}

\section{Complicação abdominal de derivação ventricular}

Jose Albuquerque Landim Júnior ${ }^{1}$. Valcler Antonio Cabral Rodrigues ${ }^{1}$. Willy Okoba ${ }^{1}$. Elson Arruda Linhares ${ }^{2}$. Jose Ricardo Cunha Neves ${ }^{3}$. Arthur Guimarães Filho ${ }^{3}$.

1 Residência em cirurgia, Hospital Santa Casa de Misericordia de Sobral, Ceará, Brasil. 2 Cirurgião geral, Hospital Santa Casa de Misericordia de Sobral, Ceará, Brasil. 3 Professor, Departamento de cirurgia, Universidade Federal do Ceará, Campus Sobral, Ceará, Brasil.

\section{ABSTRACT}

The ventriculoperitoneal shunt (VPS) is a solution to relieving symptoms of excess cerebral-ventricle cerebrospinal fluid (CSF); draining this extra fluid to the peritoneum. Other forms of shunts exist though less used in relation to VPS; whose choice is mainly determined by patient's clinical presentation and regressive history. Though rare, VPS is not devoid of complications. Furthermore, primary abdominal complications are rarer, though most present as peritonitis, abscess or shunt catheter dissociation, each with varying short and long term consequences. Recently, abdominal fluid collections are drawing increasing interest, particularly in relation to: encysted collections (abdominal pseudocysts-APC) and excess cerebrospinal fluid (CSF) accumulation (called CSF ascites). We present a case of an abdominal APC diagnosed in an outpatient treated at our referral centre, and explore the involved clinical and surgical aspects. This patient was successfully treated and evolved well post-operatively and up-to-date. Despite vast evolution in neurosurgery, VPS continues being the prima choice in treating hydrocephalus, a procedure prone to complications just like any surgery, though rare. Non-draining shunts usually warrant revision which usually means at least a reoperation. Mechanisms leading to APC formation remain unknown, although a previous bout of sub-clinical peritonitis continues being the dominant hypothesis.

Keywords: General surgery. Ventriculoperitoneal shunt. Abdomen.

\section{RESUMO}

A derivação ventrículo-peritonial é um procedimento executado para aliviar sintomas de hidrocefalia, drenando o liquor em excesso do sistema ventricular para o peritônio. Outros sistemas de derivação existem, mas a derivação ventriculo-peritoneal (VPS) é o mais realizado, uso determinado pela historia pregressa e apresentação clinica do paciente. Embora raras, complicações relacionadas ao implante do VPS existem. Mais raras ainda são as complicações abdominais, que podem acontecer na fase aguda ou crônica e que na maioria das vezes cursam com peritonite, abscesso intra-abdominal ou dissociação dos componentes do cateter, segundo a literatura. Atualmente, vem aumentando interesse pelas coleções císticas (APC) ou asciite (CSF) e os fatores relacionados a essas complicações da VPS. Apresentamos um caso clínico de um paciente diagnosticado com APC no nosso ambulatório e exploramos aspectos clínicos e cirúrgicos envolvidos; incluindo o tratamento oferecido ao paciente. O mesmo se encontra em acompanhamento em nosso ambulatório até no momento, sem intercorrências. De fato, derivações não funcionantes requerem revisão, incluindo cirurgia em uns casos. Fatores que dispõe a formação de APC continuam desconhecidos, embora um quadro de peritonite prévia continue sendo a hipótese dominante.

Palavras-chave: Cirurgia geral. Derivação ventrículo-peritoneal. Abdomen.

Corresponding author: Wlly Okoba, Rua Dr Bezerrinha, 245, Rodolfo Teofilo, Fortaleza, Ceará. CEP: 60430-150.Telefone: +55 85 98636-6653. E-mail: camaradavili@yahoo.ca

Conflict of interests: The authors have no conflicts of interest to declare.

Received: 20 Nov 2015; Revised: 11 Jul 2016; Accepted: 17 Aug 2016. 


\section{INTRODUCTION}

The ventriculoperitoneal shunt (VPS) is a surgery, executed with the intent to relieve the symptoms and signs caused by excess cerebrospinal fluid (CSF) in the ventricle, draining the extra fluid to other parts of the body, this case the peritoneum. This excess CSF if not drained culminates to hydrocephalus; a consequence of an aqueduct stenosis, or other passage obstacles in the CSF pathway, or straightforward high CSF production or cerebral edema as in the case of subarachnoid hemorrhage, trauma, or infection of the neurocranium or some specific congenital conditions. ${ }^{1}$ There exist other forms of shunts, whose choice are determined by patient's clinical presentation and pathological history. ${ }^{2}$ Just as any other surgical procedure, VPS is not devoid of complications; although such are rare. Primary abdominal complications related to VPS are rare, with most presenting as peritonitis, abscess or shunt catheter dissociation. ${ }^{3}$ Of these, peritoneal complications involving the intraperitoneal lodged distal end of the shunt tube vary from $10 \%$ to $30 \%{ }^{4}$ This includes cases involving migration of the distal catheter has been reported with varying complications: thoracic,${ }^{5}$ oral, ${ }^{6}$ mammary, ${ }^{7}$ vascular, ${ }^{8}$ hepatic ${ }^{9}$ and perineal. ${ }^{10}$ However, abdominal fluid collections are relatively uncommon (approximately $2 \%$ ), with presentations being of two principal characteristics: encysted collections (abdominal pseudocysts-APC) and excess cerebrospinal fluid (CSF) accumulation (called CSF ascites). ${ }^{11}$

We describe the case of a patient diagnosed with abdominal cystic mass, associated with probable intestinal webs. He presented at our out-patient section and was subsequently managed conservatively for a progressive history of frequent alterations of the intestinal rhythm characterized mostly by constipation, associated with progressive abdominal distention over three years. Over this period, no significant progress was yielded upon which the patient was programmed for an investigative radiological imaging and laparoscopy.

\section{CASE PRESENTATION}

A 49-year-old man, of Latin-American origin was admitted to our elective pre-operative surgery ward pending diagnostic laparotomy for a giant abdominal cyst. Over three years, he had frequent check-ups for the aforementioned progressive growing mass, associated with chronic constipation and vague abdominal pains. Conservative follow-up yielded no significant melioration of his general status. Upon independent radiological imaging, the nature of this mass was confirmed with a venous contrast enhanced abdominal computed tomography which showed a $14.9 \mathrm{~cm} \times 9.3 \mathrm{~cm}$ cystic mass, extending from the superior abdomen, intimate with the gall bladder, up to the pelvic rim. This complemented an earlier executed abdominal ultrasound which suggested a 'large' cystic abdominal mass alongside intestinal webs. The abdominal tomography suggested that the cyst exercised a 'compressive' effect on other abdominal organs, including the bowels. Furthermore, a radio-opaque line was seen juxta-positioned to the cyst, with the latter 'probably' enveloping its distal end (Figure 1). However, the cyst did not capture any contrast.

Figure 1. Sequence of computarized tomography showing the extent of the cystic mass. (a) the X-ray scout with the white arrows delimiting the coronal extention of the distal catheter. The thoracic portion of the Ventricle-peritoneal shunt (b) and (c). The abdominal portion of the Ventricle-peritoneal shunt (d) through (g). Note the cyst extention, from the Morrison space, just below the gall bladder, righ into the pelvic girgle.

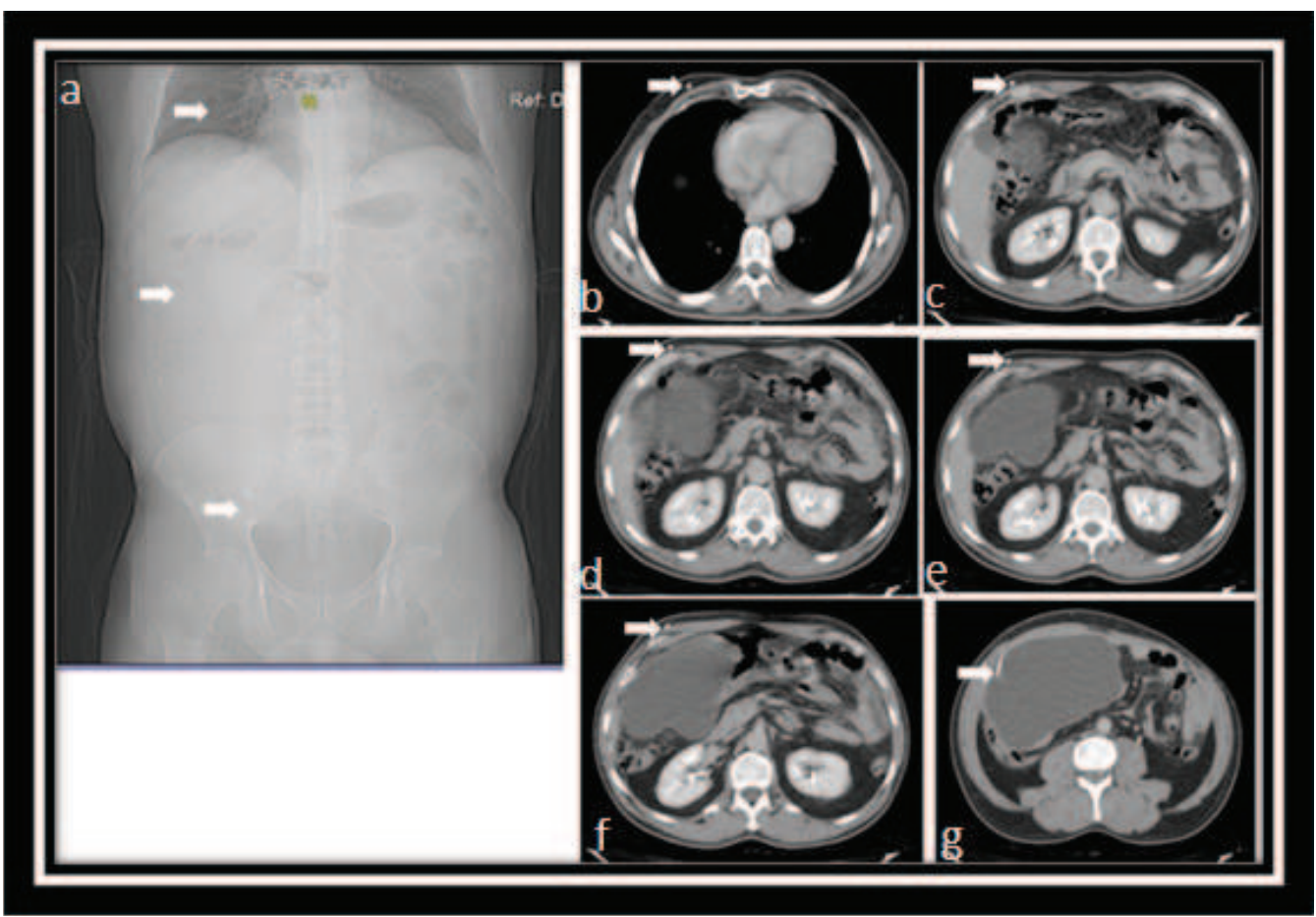


The patient referred to a VPS surgery for hydrocephalus, 22 years ago. However, he could not record whether the shunt needed subsequent revision. Ever since, he was asymptomatic.

The patient was submitted to laparotomy where a massive non-septed cyst with a volume of approximately $1600 \mathrm{ml}$ serous liquid (Figure 2) was seen adhering to the gall bladder and the hepatic hilar bed, superiorly, extending caudally to the rim just below the pelvic girdle and intimate with the bladder. Its medial and lateral walls were intimately attached with the small intestine and the ascending colon respectively, with intense mature meshwork of fibrous webs holding up its position. As expected, the enveloping shunt-line had its distal tip engorged in the pseudocyst (Figure 2a). A thick mesh of adhesion webs was evident with cumulative bowel distention with enteric matter, right from the angle of Treitz.

Figure 2. A: The ressescted abdominal pseudocyst engulfing the distal tip of the VP-Shunt catheter. B: The ressescted, with the catheter retrieved from its interior. C: After complete evacuation of the ressescted abdominal pseudocyst.

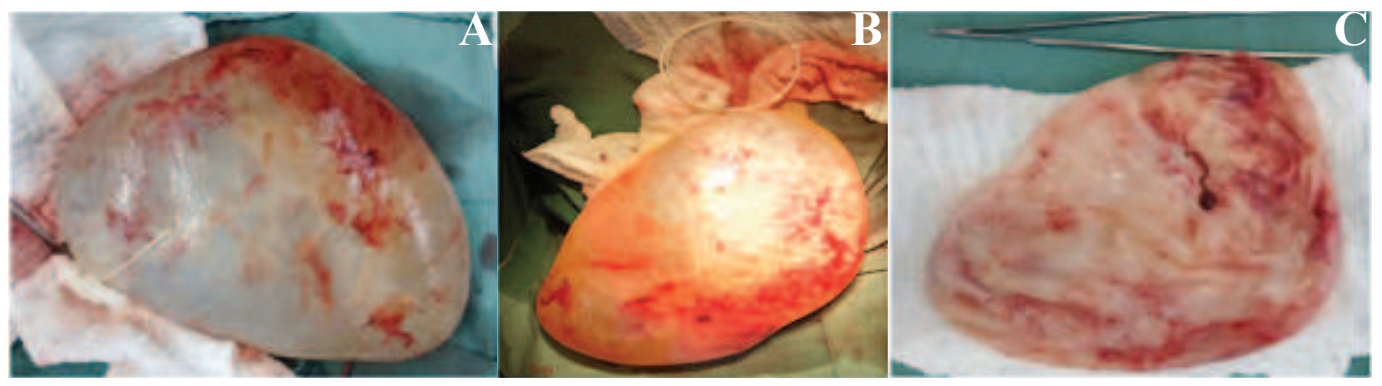

The pseudocyst was carefully dissected, separating it from its bed (Figure $2 \mathrm{~b}$ and $2 \mathrm{c}$ ), with a corrective enterectomy, followed by primary anastomosis and repositioning of the shunt line in the peritoneal bed. The patient evolved well post-operatively. The anatomohystological study on the pseudocyst was confirmed after histological study; composed of a fibro-vascular, epithelium-less wall, thickly infiltrated with fibrin and a strange body cells-type chronic inflammation. No signs of malign cells were seen.

\section{DISCUSSION}

Since the last century, the VPS has been the preferred therapy for chronic hydrocephalus..$^{1,12}$ The procedure entails inserting a shunt into the enlarged non-draining ventricle, often with a valve to regulate the rate of drainage, conferring the proximal shunt. This is then connected to a second shunt, which extends over the thorax subcutaneously before it is tunneled into the peritoneum, the distal portion. Between the two portions, there is a one-way valve whose intent is to prevent reflux of cerebral spinal fluid into ventricles. When compared to other shunt alternatives, VPS manifest fewer complications. ${ }^{12}$ Though uncommon, shunt revision is warranted so as to repair non-draining shunts. Usually, the non-functioning distal portion is replaced with a patent one; leaving the former within the abdominal cavity, thus simplifying the procedure. Additionally, the valve itself or an abdominal fluid accumulation can be tapped for cell counts and microbiological specimens of possibly infected CSF. Depending on whether the shunt tube is involved in, or surrounded by, infectious material, the system might be left in place after abdominal revision, unless infection process is present and it involves the non-functioning VPS. ${ }^{13}$ Usually, cultures are carried out, followed by antibiotic-based therapy. These distal malfunctioning shunt segments are frequently referred to as abandoned, orphaned, redundant, or disconnected shunt catheters.
Complications of functioning VPS are well documented: varying from shunt malfunction, infection, disjunction, migration to perforation of vital abdominal or thoracic organs. ${ }^{5}$ Documented complications of abandoned ventriculoperitoneal (VP) shunts are rare, with few occurrences seldom documented, ${ }^{14}$ hence quite difficult to estimate their morbidity and mortality. For instance, spontaneous per anus passage of a distal end of a non-functioning VP shunt has been noted during a routine colon preparation for colonoscopy. ${ }^{14}$ The patient cited in this case was asymptomatic. Established protocols on how to manage silent abandoned-shunt complications are nonexistent. Most of the few documented cases are managed, at most, conservatively with wide-spectrum coverage antibiotics.

Since VP shunts are installed mostly in infant patients usually before their $10^{\text {th }}$ birthday, this population caters for more than half of all complications, mostly in non-ambulatory patients. ${ }^{4,15}$ The sigmoid and transverse colon are the most frequent sites of perforation, followed by the stomach. ${ }^{15}$ Furthermore, many mechanisms for intact VP shunt migration have been suggested, including inadequate catheter length, failure to fix the shunt firmly to adjacent tissue, foreign body reaction, silicone allergy, formation of fibrous sheath and local pressure, use of spring-loaded shunts, use of both hard and soft tipped silicone shunts, inoculation of the shunt with bacteria during insertion, and use of trocar technique. ${ }^{5-10}$ Probably, abandoned VP shunts migrate via similar mechanisms.

Mortality due to bowel perforation by intact VP shunts prevails at approximately $15 \%,{ }^{4}$ however no data exist in relation to abandoned or non-functioning shunts. Clinical presentation varies and is usually nonspecific: abdominal pain with an elevated white blood count, diarrhea, and gastroenteritis. More obvious signs such as meningitis with gram negative and anaerobic organisms ${ }^{16}$ are also common, postulating ascension by enteric organisms through an intact shunt into the central nervous system. Whether this hypothesis holds 
water in relation to abandoned shunts, is yet to be postulated. Thus, it is inconclusive to draw a correlation explaining the pathophysiology of meningitis related to abandoned VP shunts. Risk for overt peritonitis has been suggested due to the likelihood of a patent communication between the invaded bowel lumen and the peritoneum. Few publications advocate for surgical or laparoscopic removal of the non functioning distal catheter, however in a stable and non-symptomatic patient. ${ }^{15}$ Since most patients have multiple co-morbidities, though asymptomatic in relation to bowel perforation, abandoned VP are mostly conservatively managed, unless otherwise.

While there is no risk of meningitis in patients with abandoned VP shunts, there is a theoretical risk of peritonitis, which must be weighed when deciding how best to treat such a patient. Radiologists must remain vigilant when reviewing studies of

\section{REFERENCES}

1. Moza K, McMenomey SO, Delashaw JB Jr. Indications for cerebrospinal fluid drainage and avoidance of complications. Otolaryngol Clin North Am. 2005;38(4):577-82.

2. McKusick KA, Malmud LS, Kordela PA, Wagner HN Jr. Radionuclide cisternography: normal values for nasal section of intrathecally injected 111In-DTPA. J Nucl Med. 1973;14(12):933-4.

3. Turner R, Chahlavi A, Rasmussen P, Brody F. Laparoscopic revision of a ventriculoperitoneal shunt. J Laparoendosc Adv Surg Tech A. 2004;14(5):310-12.

4. Wu Y, Green NL, Wrensch MR, Zhao S, Gupta N. Ventriculoperitoneal shunt complications in California: 1990 to 2000. Neurosurgery. 2007;61(3):557-63.

5. Doh JW, Bae HG, Lee KS, Yun IG, Byun BJ. Hydrothorax from intrathoracic migration of a ventriculoperitoneal shunt catheter. Surg Neurol. 1995;43(4):340-3.

6. Berhouma M, Messerer M, Houissa S, Khaldi M. Transoral protrusion of a peritoneal catheter: a rare complication of ventriculoperitoneal shunt. Pediatr Neurosurg. 2008;44(2):169-71.

7. Chu YT, Chuang HC, Lee HC, Cho DY. A ventriculoperitoneal shunt catheter wrapped around a right mammary prosthesis forming a pseudocyst. J Clin Neurosci. 2010;17(6):801-3.

8. Hermann EJ, Zimmermann M, Marquardt G. Ventriculoperitoneal shunt migration into the pulmonary artery. Acta Neurochir (Wien). 2009;151(6):647-52. patients with VP shunts, as migration and perforation may be easily missed, especially when the patient's symptoms or imaging indication is not obviously related to shunt complications.

Once shunt dysfunction or abdominal symptoms occur, a thorough physical examination is warranted, especially because VP-shunt-bearing patients frequently are not capable of adequate verbal expression. Neurological symptoms of raised intracranial pressure, such as headache, nausea, vomiting, impaired gait, nuchal rigidity, seizures, and others, in combination with abdominal pain, abdominal distention, abdominal wall rigidity, or local irritation, merit further evaluation by imaging or other diagnostic procedures, such as CT abdomen, endoscopy, or even laparoscopy and should lead to diagnosis.

9. Berkmann S, Schreiber V, Khamis A. Recurrent intrahepatic dislocation of ventriculoperitoneal shunt. Minim Invasive Neurosurg. 2011;54(2):83-6.

10. Ghritlaharey RK, Budhwani KS, Shrivastava DK, Gupta G, Kushwaha AS, Chanchlani R, et al. Transanal protrusion of ventriculo-peritoneal shunt catheter with silent bowel perforation: report of ten cases in children. Pediatr Surg Int. 2007;23(6):575-80.

11. Kariyattil R, Steinbok P, Singhal A, Cochrane DD. Ascites and abdominal pseudocysts following ventriculoperitoneal shunt surgery: variations of the same theme. J Neurosurg. 2007;106:350-3.

12. Keucher TR, Mealey J. Long-term results after ventriculoatrial and ventriculoperitoneal shunting for infantile hyrocephalus. J Neurosurg. 1979;50(2):179-86.

13. Nfonsam V, Chand B, Rosenblatt S, Turner R, Luciano M. Laparoscopic management of distal ventriculoperitoneal shunt complications. Surg Endosc. 2008;22(8):1866-70.

14. Thipphavong S, Kellenberger CJ, Rutka JT, Manson DE. Hepatic and colonic perforation by an abandoned ventriculoperitoneal shunt. Pediatr Radiol. 2004;34(9):750-2.

15. Vinchon M, Baroncini M, Laurent T, Patrick D. Bowel perforation caused by peritoneal shunt catheters: diagnosis and treatment. Neurosurgery. 2006;58(1 Suppl):ONS76-82.

16. Abdel WM. E. Coli meningitis as an indicator of intestinal perforation by V-P shunt tubes. Neurosurg Rev. 1998;21:194-7.

\section{Como citar:}

Landim JA Júnior, Rodrigues VA, Okoba W, Linhares EA, Neves JR, Guimarães A Filho. Ventricule-shunt abdominal complications. Rev Med UFC. 2017 jan-abr;57(1):48-51. 